\title{
Performance of Bottle Gourd Selections under Sub-Montane Zone of Maharashtra, India
}

\author{
V.K. Garande*, U.B. Palghadmal, D.R. Padgaonkar, P.N. Sonawane, \\ S.S. Dhumal and R.D. Pawar
}

\author{
Horticulture Section, College of Agriculture, Kolhapur-416 004, Maharashtra State, India \\ *Corresponding author
}

\section{A B S T R A C T}

The present investigation was carried out at College of Agriculture, Kolhapur during the Kharif 2016. The promising selections of bottle gourd made at MPKV, Rahuri were evaluated for their growth and yield performance under Kolhapur conditions which comes under sub montane zone of Maharashtra. The data revealed, that among different selection of bottle gourd, RHRBG - 19 had recorded minimum days required for germination (6.00 days), minimum days required for appearance of first male (36.33 days) and female flower (39.66 days) and minimum number of inter-node at which first male (4.00) and female flower $\left(11.20^{\prime}\right.$ as compared with the remaining selections. The selection RHRBG -19 also

Keywords

Bottle gourd selections,

Germination, Growth,

Yield and yield contributing

characters.

Article Info

Accepted:

24 September 2017

Available Online:

10 November 2017 recorded the maximum number of female flowers (33.00), maximum fruit length (38.53 $\mathrm{cm})$, highest diameter $(7.62 \mathrm{~cm})$ and average fruit weight $(690.00 \mathrm{~g})$ and minimum number of days required for $50 \%$ flowering (42.66) as compared with the remaining selections under study. Similarly the selection RHRBG -19 recorded more number of fruits per vine (23.00), highest fruit yield/vine $(15.87 \mathrm{~kg})$ and per hectare $(529.00 \mathrm{q})$ followed by RHRBG - 18 which recorded female flower (31.33), fruit length (35.73), diameter (7.24), average fruit weight $(608.00 \mathrm{~g})$, number of fruits per vine (22.20), fruit yield/vine (13.37) and per hectare $(449.66 \mathrm{q})$. The elongated fruit shape was observed in the selections such as RHRBG -1, HRBG - 3, RHRBG -19, RHRBG -24, RHRBG -27, RHRBG - 30, RHRBG 36 and the HRBG - 23 while the cylindrical fruit shape was observed in the remaining selections of bottle gourd such as RHRBG -18 and RHRBG -22. The deep green colour was observed in the selections such as RHRBG -1, RHRBG -3, RHRBG -18, RHRBG 24 and RHRBG - 36 and pale green colour of bottle gourd fruits was observed in RHRBG -19 and RHRBG - 23, while the medium green colour was observed in selections RHRBG -22 and RHRBG -30. The medium pubescence were observed in the selections such as RHRBG - 1, RHRBG -3, RHRBG- 19, RHRBG -22, RHRBG- 23, RHRBG -24, RHRBG30 and RHRBG - 36 and dense pubescence were observed in the selections RHRBG - 18 and RHRBG -27 while the medium pubescence on the fruits was observed in remaining selections such as RHRBG -1, RHRBG -3, RHRBG -19, RHRBG -22, RHRBG -23, RHRBG -24, RHRBG -30 and RHRBG -36.

\section{Introduction}

Bottle gourd (Lagenaria siceraria [Mol.] Standl.) belongs to the family Cucurbitaceae, is one of the most important cucurbitaceous crops in India and grown in rainy season as well as summer season vegetable but its fruits are available in the market throughout the 
year. It is also known as "poor man's vegetable" in India. This delicious vegetable is also known by different names such as quash, calabash gourd, doodhi and lauki, birdhouse gourd, trumpet gourd and white flowered gourd (Thakur et al., 2015).

Bottle gourd is used for preparation of burfi, juice, raita, kaporkand, pickles, kofta, doodhi halwa etc. are also common. It has a cooling effect and prevents constipation and has diuretic and cardio tonic properties. Regular consumption of this vegetable provides relief to people suffering with digestive problems and used for reducing the blood sugar in diabetic patients. Nutritional value of bottle gourd per $100 \mathrm{~g}$ of edible portion is $96.1 \%$ moisture, $0.2 \mathrm{~g}$ proteins, $0.1 \mathrm{~g}$ fat, $0.5 \mathrm{~g}$ mineral, $0.7 \mathrm{mg}$ fiber, $2.5 \mathrm{~g}$ carbohydrates, 12 kcal energy, $20 \mathrm{mg}$ calcium, $10 \mathrm{mg}$ phosphorus, $0.2 \mathrm{mg}$ niacin, $0.01 \mathrm{mg}$ riboflavin, $0.03 \mu \mathrm{g}$ thiamine and it is also rich source of minerals like iron and vitamins like C and B complex (Singh and Singh, 2014).

The area under bottle gourd cultivation in India is reported to be 111 thousand hectares with annual production of 1836 thousand metric tons. The bottle gourd growing leading states in India are Rajasthan, Gujarat, Punjab, Uttar Pradesh, Bihar, West Bengal, Madhya Pradesh, Maharashtra, Andhra Pradesh and Tamil Nadu (Anon, 2015). Preliminary identification of early maturing genotype can be done based on characters like days to opening of female flower, node number to first female flowering and days to fruit picking (Harika et al., 2012). In Maharashtra a large number of local types are being cultivated. Most of the growers cultivate this crop by using either their own seeds or available seeds in market. There is an urgent need of the farmers is to develop early maturing and high yielding varieties/hybrids of bottle gourd. Collection and evaluation of germplasm is a pre-requisite for their utilization and detailed evaluation determines the potential of an accession in specific crop improvement programme the different selections were made by AICRP on vegetable improvement, MPKV Rahuri are need to be evaluated for their growth and yield performance. Therefore, the present investigation was carried out to study the growth performance, yield and yield contributing characters of bottle gourd selections under sub montane zone of Maharashtra.

\section{Materials and Methods}

The present investigation was carried out at the Instructional-cum-Research farm of Horticulture Section, College of Agriculture, Kolhapur during the Kharif season of year 2016. The experimental field was ploughed with MB plough followed by planking in order to bring the soil to fine tilth. The required area was marked and 30 plots were prepared according to the layout plan. Pure and healthy seeds of 10 selections of bottle gourd were sown in the field in randomized block design with three replications. The recommended dose of fertilizers i.e. $100 \mathrm{~kg}$ $\mathrm{N}, 50 \mathrm{~kg} \mathrm{P}_{2} \mathrm{O}_{5}$ and50 $\mathrm{kg} \mathrm{K}_{2} \mathrm{O}$ was applied to the soil and the entire quantity of phosphorus and potassium and half of nitrogen was mixed thoroughly in each plot in equal amount as basal dose before sowing. The well rotten FYM@40 tons per hectare was mixed thoroughly in the soil before seed sowing. The top dressing of half nitrogen was applied after one month of planting and second done was given at the time of flowering. The planting distance used for the present investigation was $3 \times 1 \mathrm{~m}$ and sowing was done on $27^{\text {th }}$ July 2016. The recommended packages of practices were followed during the period of present experimentation.

The fruits were harvested along with talk at 34 days interval when fruit colour change is 
light green. Five plants from the population were randomly selected for recording the observations on growth performance, yield and yield contributing characters and quality of bottle gourd fruits. The data generated through the present investigation was subjected to statistical analysis (Panse and Sukhatme (1985).

\section{Results and Discussion}

\section{Growth parameters}

The data presented in Table 1 revealed that the significantly minimum number of days required for seed germination were noticed in bottle gourd selection RHRBG - 19 (6.00 days), whereas maximum number of days were required for germination of seeds of RHRBG - 36 (9.66 days). The variation in days required for germination of seeds of selections of bottle gourd might be due to varietal difference. Similar results were reported by Kumar et al., (2007) in bottle gourd and Hossain et al., (2010) in seeds of cucumber. The bottle gourd selections were found to be differed significantly with respect to mean number of days required for appearance of first male flower (Table 1). The maximum number of days required for appearance of first male flower were noticed in the selection RHRBG - 30 (51.73 days) whereas the lowest mean number of days required for appearance of first male flower in the selection RHRBG - 19 (36.33).

The selections RHRBG - 30 had recorded the maximum number of days required for appearance of first male flower (55.16 days) which were found to be significantly highest among all the selections of bottle gourd under study (Table 1). The significantly lowest number of days required for appearance of first female flower in the selection RHRBG 19 (39.66 days). The difference in flowering period among the different selections might be due to genetic variation. The similar results were reported by Harika et al., (2012) Yadav and Kumar (2012), Uddin et al., (2014), Singh and Singh (2014), Thakur et al., (2015) in bottle gourd.

The first male flower was appeared on 3.16 internode in the selection RHRBG -23 which was significantly superior over the remaining selections and followed by RHRBG -19 (4.00) while the selection RHRBG - 3 recorded the first male flower on $8^{\text {th }}$ internode (Table 1). Internodal position of the first female flower on the vine is very important and desirable characteristics in bottle gourd which has association with earliness. The first female flower was observed at11.33 internode in RHRBG - 19 while the selection RHRBG -1 recorded lowest internode for production of female flower (Table 1). The genotypes giving more number of fruits at lower nodes along with early fruit set and harvest resulted higher and early yields. The present findings are in agreement with the results of Nalawade, et al., (2011) in bitter gourd, Samadia (2011), Shinde et al., (2014), Singh and Singh (2014) in bottle gourd and Sahu et al., (2015) in ash gourd.

The data revealed that the significant differences were observed with respect number of male flowers per vine (Table 1). The maximum number of male flowers per vine were noticed in RHRBG - 36 (347.33/ vine) which were significantly superior over the remaining selections of bottle gourd, whereas the selection RHRBG - 19 (239.66/vine) recorded the lowest number of male flowers per vine. Similarly Shinde et al., (2014) reported that the selection Samridhi had recorded significantly minimum number of male flowers per vine (273.05) and maximum numbers of male flowers per plant were recorded in selection Local in bottle gourd (356.62). Number of female flowers per vine has direct relation with the fruit set. 
Table.1 Growth performance of bottle gourd selections under sub mountain zone of Maharashtra

\begin{tabular}{|c|c|c|c|c|c|c|c|c|c|}
\hline \multirow[t]{2}{*}{$\begin{array}{l}\text { Sr. } \\
\text { No. }\end{array}$} & \multirow[t]{2}{*}{$\begin{array}{l}\text { Name of } \\
\text { selection }\end{array}$} & \multirow{2}{*}{$\begin{array}{l}\text { Number of days } \\
\text { required for } \\
\text { seed germination }\end{array}$} & \multicolumn{2}{|c|}{$\begin{array}{c}\text { Appearance of first } \\
\text { flower }\end{array}$} & \multicolumn{2}{|c|}{$\begin{array}{c}\text { Node number at which first } \\
\text { flower appeared }\end{array}$} & \multicolumn{2}{|c|}{$\begin{array}{c}\text { Number of flowers per } \\
\text { vine }\end{array}$} & \multirow[t]{2}{*}{$\begin{array}{l}\text { Days to } 50 \% \\
\text { flowering }\end{array}$} \\
\hline & & & Male & Female & Male & Female & Male & Female & \\
\hline 1. & RHRBG - 1 & 8.66 & 48.26 & 50.73 & 7.18 & 15.13 & 325.66 & 24.16 & 54.16 \\
\hline 2. & RHRBG - 3 & 7.66 & 44.06 & 46.53 & 8.00 & 14.86 & 316.33 & 24.40 & 48.00 \\
\hline 3. & RHRBG- 18 & 7.00 & 40.26 & 43.33 & 5.00 & 13.00 & 254.00 & 31.33 & 46.00 \\
\hline 4. & RHRBG -19 & 6.00 & 36.33 & 39.66 & 4.00 & 11.20 & 239.66 & 33.00 & 42.66 \\
\hline 5. & RHRBG -22 & 7.66 & 41.00 & 44.60 & 6.20 & 13.43 & 313.66 & 22.00 & 53.66 \\
\hline 6. & RHRBG -23 & 7.00 & 41.60 & 45.00 & 3.16 & 13.53 & 281.00 & 31.00 & 48.00 \\
\hline 7. & RHRBG- 24 & 8.00 & 44.46 & 47.46 & 6.26 & 14.00 & 316.33 & 27.66 & 50.00 \\
\hline 8. & RHRBG -27 & 8.00 & 45.33 & 49.26 & 7.33 & 14.86 & 323.33 & 26.33 & 52.00 \\
\hline 9. & RHRBG- 30 & 9.33 & 51.73 & 55.16 & 6.16 & 13.70 & 328.00 & 29.06 & 59.00 \\
\hline 10. & RHRBG -36 & 9.66 & 46.20 & 53.33 & 7.00 & 15.06 & 347.33 & 29.00 & 55.00 \\
\hline \multicolumn{2}{|c|}{$\mathrm{SE} \pm$} & 0.40 & 1.51 & 0.68 & 0.35 & 0.69 & 3.52 & 1.16 & 1.06 \\
\hline \multicolumn{2}{|c|}{$\mathrm{CD}$ at $5 \%$} & 1.19 & 4.59 & 2.03 & 1.04 & 2.07 & 10.46 & 3.45 & 3.17 \\
\hline
\end{tabular}

Table.2 Yield, yield contributing characters and quality of bottle gourd selections under sub mountain zone of Maharashtra

\begin{tabular}{|c|c|c|c|c|c|c|c|c|c|c|c|}
\hline $\begin{array}{l}\text { Sr. } \\
\text { No. }\end{array}$ & $\begin{array}{l}\text { Name of } \\
\text { selection }\end{array}$ & $\begin{array}{c}\text { Fruit } \\
\text { length } \\
(\mathrm{cm})\end{array}$ & $\begin{array}{c}\text { Fruit } \\
\text { diameter } \\
(\mathbf{c m})\end{array}$ & $\begin{array}{c}\text { Weight } \\
\text { of fruit } \\
\text { (g) }\end{array}$ & $\begin{array}{c}\text { No. of } \\
\text { fruits } \\
\text { Per vine }\end{array}$ & $\begin{array}{c}\text { Fruit } \\
\text { yield per } \\
\text { vine }\end{array}$ & $\begin{array}{c}\text { Fruit } \\
\text { yield } \\
\text { (q/ ha) }\end{array}$ & $\begin{array}{c}\text { No. of } \\
\text { harvestings }\end{array}$ & $\begin{array}{l}\text { Colour of } \\
\text { fruit }\end{array}$ & Shape of fruit & $\begin{array}{c}\text { Presence } \\
\text { pubescence } \\
\text { on fruit }\end{array}$ \\
\hline 1. & RHRBG - 1 & 29.20 & 5.47 & 459.66 & 18.33 & 8.41 & 282.04 & 14.66 & Deep green & Elongated & Medium \\
\hline 2. & RHRBG - 3 & 29.13 & 5.53 & 461.66 & 18.86 & 8.69 & 289.66 & 14.00 & Deep green & Elongated & Medium \\
\hline 3. & RHRBG- 18 & 35.73 & 7.24 & 608.00 & 22.20 & 13.49 & 449.66 & 17.00 & Deep green & Cylindrical & Dense \\
\hline 4. & RHRBG -19 & 38.53 & 7.62 & 690.00 & 23.00 & 15.87 & 529.00 & 17.66 & Pale green & Elongated & Medium \\
\hline 5. & RHRBG -22 & 28.33 & 4.19 & 385.66 & 17.00 & 6.54 & 217.77 & 13.66 & Medium green & Cylindrical & Medium \\
\hline 6. & RHRBG -23 & 35.00 & 7.17 & 606.66 & 22.13 & 13.41 & 446.99 & 16.66 & Pale green & Curved elongated & Medium \\
\hline 7. & RHRBG- 24 & 34.46 & 6.15 & 506.33 & 20.80 & 10.52 & 350.66 & 15.00 & Deep green & Elongated & Medium \\
\hline 8. & RHRBG -27 & 31.33 & 5.43 & 426.66 & 19.00 & 8.09 & 269.55 & 15.00 & Deep green & Elongated & Dense \\
\hline 9. & RHRBG- 30 & 34.66 & 7.05 & 582.00 & 22.00 & 12.81 & 427.00 & 16.33 & Medium green & Elongated & Medium \\
\hline 10. & RHRBG -36 & 30.06 & 6.93 & 575.00 & 20.66 & 11.88 & 395.97 & 16.00 & Deep green & Elongated & Medium \\
\hline \multicolumn{2}{|c|}{$\mathrm{SE} \pm$} & 2.06 & 0.19 & 12.25 & 0.94 & 0.48 & 20.08 & 0.71 & -- & --- & -- \\
\hline \multicolumn{2}{|c|}{$\mathrm{CD}$ at $5 \%$} & 6.13 & 0.57 & 36.40 & 2.80 & 1.44 & 60.24 & 2.12 & --- & --- & -- \\
\hline
\end{tabular}


The highest number of female flowers per vine were recorded in selection RHRBG - 19 (33.00) and RHRBG -18 (31.33) but it was at par with RHRBG 23 (31.00), while lowest number of female flowers were recorded in RHRBG 22 (22.00). Shinde et al., (2014) recorded maximum number of female flower per vine in selection Pusa Samridhi (36.63) while minimum number female flowers were recorded in selection Local (28.83). Similarly Nalawade et al., (2011) reported that the maximum number of female flowers per vine in variety Priya (28.33) of bitter gourd. The maximum number of days to $50 \%$ flowering were recorded in selection RHRBG -30 (59.00 days), whereas minimum number of days were recorded in RHRBG -19 (42.66 days). The variation in days to $50 \%$ flowering in bottle gourd selections might be due to genetic variation in the selections. Similar results were reported by Dhanwate et al., (2011) in bitter gourd.

\section{Yield and yield contributing characters}

The data with respect fruit length was found to be differed significantly among the selections under study (Table 2). The highest fruit length was recorded in selection RHRBG - $19(38.53 \mathrm{~cm})$, whereas the lowest fruit length was recorded in selection RHRBG -22 $(28.33 \mathrm{~cm})$. The results of present finding are in close conformity with the results of Harika et al., (2012) who observed the considerable variability in fruit length ranged from $9.18 \mathrm{~cm}$ (Elina) to $58.92 \mathrm{~cm}$ (Anand bottle gourd -1). The average fruit diameter was found to be differed significantly among the selections of bottle gourd (Table 2). The maximum diameter of fruit was recorded in RHRBG $19(7.62 \mathrm{~cm})$ followed by RHRBG - 18 (7.24 $\mathrm{cm})$ and RHRBG $-23(7.17 \mathrm{~cm})$ whereas the selection RHRBG - 22 recorded the lowest mean fruit diameter $(4.19 \mathrm{~cm})$. The difference in fruits diameter could be attributed to inherent characteristics of the genotypes. The fruit diameter increase with the increase in size of fruit. These results are in agreement with the results obtained by Harika et al., (2012) in bottle gourd, Sharma and Sengupta (2013), Singh and Singh (2014) Deepthi et al., (2016) in bottle gourd under different growing conditions. The average fruit weight directly contributes to the fruit yield of bottle gourd. The maximum fruit weight was recorded in RHRBG -19 (690.00 g) which was significantly superior among the different selections of bottle gourd (Table 2). The lowest average fruit weight was recorded by the selection RHRBG -22 (385.66 g) followed by RHRBG -27 (426.66 g) and RHRBG -3 (461.66g). Similarly Sharma and Sengupta (2013) reported that fruit yield per plant had positive and highly significant correlation with average fruit weight of bottle gourd. The selection RHRBG -19 produced more number of fruits per vine (23.00) and RHRBG - 18 (22.20) but it was at par with RHRBG - 23 (22.13). The selection RHRBG - 22 recorded the lowest number of fruits per vine (17.00). The variation in fruits per vine might be due to internodal length, increased female flower and fruit set percentage. Similar results were obtained by Sharma and Sengupta (2013), Shinde et al., (2014), Singh and Singh (2014), Uddin et al., (2014) and Thakur et al., (2015) in bottle gourd.

The data pertaining to fruit yield per vine revealed that the highest fruit yield per vine (15.87 kg/vine) was recorded in RHRBG -19 which was significantly superior over the other selections of bottle gourd under study (Table 2). The lowest fruit yield per vine was recorded in the selection RHRBG - 22 (6.54 $\mathrm{kg})$ followed by RHRBG $-27(8.09 \mathrm{~kg})$ and RHRBG - 1(8.41 kg). The maximum fruit yield per hectare was observed in selection RHRBG -19 (529.00 q) which was found to be significantly superior over the other selections of bottle gourd. The minimum fruit yield per hectare was recorded in selection 
RHRBG - 22 (217.77 q) closely followed by RHRBG -27 (269.55q) and RHRBG -1 $(282.04 \mathrm{q})$. The variation in fruit yield of bottle gourd selection might to be due to genetic characters. The fruit yield per hectare was found to be ranged in between $213 \mathrm{q}$ (BOGVAR- 5) to $398 \mathrm{q}$ (BOGVAR - 4) as reported by Thakur et al., (2015). The mean maximum number of harvestings were recorded in selection RHRBG -19 (17.66) followed by RHRBG -18 (17) and RHRBG23 (16.66) (Table 2), while minimum number of harvestings were recorded in RHRBG - 22 (13.66) followed by RHRBG -3 (14.00) and RHRBG -1 (14.66). Similar results were reported by Harika et al., (2012), Shinde et al., (2014) and Thakur et al., (2015) in bottle gourd.

\section{Qualitative characters}

Fruit shape of bottle gourd is very important characters from consumer point of view and it is quite diversified. The data presented in Table 2 clearly indicated that the different shapes such as cylindrical, elongated and bottle shape were observed in the bottle gourd selections under study. The elongated fruit shape was observed in the selections such as RHRBG -1, HRBG - 3, RHRBG -19, RHRBG -24, RHRBG -27, RHRBG - 30, RHRBG - 36 and the HRBG - 23 while the cylindrical fruit shape was observed in the remaining selections of bottle gourd such as RHRBG -18 and RHRBG -22. The results of present findings are in close conformity with the results reported by Ara et al., (2015) who stated the wide variations shape of fruits in snake gourd. Quamruzzaman et al., (2017) observed that four types of fruit shape in bottle gourd viz., cylindrical, bottle, balloon and bottle shaped with wider neck.

The data with respect of fruit colour revealed that the significant variation was observed among the selections of bottle gourd under study (Table 2). The different colours of bottle gourd fruits such deep green, medium green and pale green were observed in the selections under study. The deep green colour was observed in the selections such as RHRBG -1, RHRBG -3, RHRBG -18, RHRBG - 24, RHRBG - 27 RHRBG - 36 and pale green colours fruits were observed in RHRBG - 19 and RHRBG - 23, while the medium green colour was observed in selections RHRBG -22 and RHRBG - 30 . The wide variations in fruit colour have been reported by Ara et al., (2015) in snake gourd. Quamruzzaman et al., (2017) observed that three types of bottle gourd colour viz., light green, green white spot and deep green with white spots. The medium pubescence were observed in the selections such as RHRBG 1, RHRBG -3, RHRBG- 19, RHRBG -22, RHRBG- 23, RHRBG -24, RHRBG- 30 and RHRBG - 36 while the dense pubescence were observed in the selections RHRBG - 18 and RHRBG -27 (Table 2). The presence of pubescence on the fruits is varietal difference and genetic character of the selections.

From the present study, it is concluded that, the selection RHRBG - 19 was found to most suitable bottle gourd selection among all the selections under study on the basis of growth parameters, yield and yield contributing characters and quality parameters under sub montane zone of Maharashtra.

\section{References}

Anonymous. 2015. National Horticulture Database, Gurgaon. New Delhi, pp. 44.

Deepthi, B., Reddy, P. S., Kumar, S. A. and Reddy, A. R. 2016. Studies on PCV, GCV, heritability and genetic advance in bottle gourd genotypes for yield and yield components. Plant Archives, 16 (2): 597- 601.

Harika, M., Gasti, V. D., Shantappa, T., Mulge, R., Shirol, A. M., Mastiholi, A. 
B. and Kulkarni, M. S. 2012. Evaluation of bottle gourd genotypes (Lagenaria siceraria (Mol.) Standl.) for various horticultural characters. Karnataka $J$. Agric. Sci., 25 (2): 241- 244.

Hussain, A., Mahmud, F., Islam, M. R., Mahmud, M. A. and Ratna, M. 2011. Genetic variability, correlation and path co- efficient analysis in bottle gourd. Advan. Biol. Res., 5(6): 323- 327.

Kumar, S., Singh, R. and Pal, A. K. 2007. Genetic variability, heritability, genetic advance correlation coefficient and path analysis in bottle gourd. Indian J. of Hort., 64(2): $163-168$.

Nalawade, N. P., Chavan, S. D., Barkule, S. R., Bhosale, A. M. and Shinde, S. J. 2011. Varietal performance of bitter gourd in respect of flowering and fruiting parameters under Parbhani district of Maharashtra. Int. J. of Agri. Sci., 7(1): 144 -146.

Panse, V. G. and Sukhatme, P. V. 1985. Statistical Methods for Agriculture workers, I. C. A. R. Publication. New Delhi, pp.97 -123.

Quamruzzaman, A. K. M., Rahman, M. M. and Akter, L. 2017. Performance of bottle gourd lines in Bangladesh conditions. Annals of Bio. Sci., 5(1):57.

Sahu,P. K., Sharma, D. S. and Nair, S. K. 2015. Performance of ash gourd genotypes for earliness and yield under
Chhattisgarh plains of India. Plant Archievs, 15(2): 1157 - 1160.

Samadia, D. K. 2011a. Genetic variability studies for improvement in bottle gourd under hot arid agro climate. Indian J. of Arid Hort., 6(1-2): 15 -18.

Sharma, A. and Sengupta, S. K. 2013. Genetic diversity, heritability and morphological characterization in bottle gourd. Int. Quarterly J. of Life Sci., 8 (4): 1461 1465.

Shinde,R. D., Vadodaria, J. R., Savale, S. V. and Vasava, H. V. 2014. Effect of nature of cultivation and different varieties on flowering, yield attributes and yield of bottle gourd (Lagenaria siceraria Mol. Standl). Trends in Bioscience, 7(24): 4320 - 4345.

Singh, B. and Singh, S. K. 2014. Evaluation trial of bottle gourd. The Asian J. Hort., 9(1): $116-119$.

Thakur, P., Sharma, D., Visen, V. K. and Dash, S. P. 2015. Evaluation of bottle genotypes. Plant Archives, 15(2): 1037 $-1040$.

Uddin, A. F. M., Tahidul, M. I., Chowdhury, M. S. N., Shiam, I. H. Mehraj. 2014. Evaluation of bottle gourd to growth and yield. International Journal of Bioscience, 5(12) 7-11.

Yadav, Y. C. and Kumar. S. 2012. Studies on genetic variability correlation coefficient and path analysis in bottle gourd. Annals of Hort., 5(1): 80 - 89.

\section{How to cite this article:}

Garande, V.K., U.B. Palghadmal, D.R. Padgaonkar, P.N. Sonawane, S.S. Dhumal and Pawar, R.D. 2017. Performance of Bottle Gourd Selections under Sub-Montane Zone of Maharashtra, India. Int.J.Curr.Microbiol.App.Sci. 6(11): 3011-3017. doi: https://doi.org/10.20546/ijcmas.2017.611.352 